\title{
Restoration of historical mansions built in Russian province at the beginning of $X X$ century
}

\author{
Maria Arlanova ${ }^{1 *}$, Sergey Pavlov ${ }^{1}$, and Leonid Yablonskii $^{2}$ \\ ${ }^{1}$ Peter the Great St.Petersburg Polytechnic University, Polytechnicheskaya, 29, St. Petersburg, \\ 195251, Russia \\ ${ }^{2}$ Saint Petersburg State University of Architecture and Civil Engineering, Vtoraya Krasnoarmeiskaya \\ str. 4. St. Petersburg, 190005, Russia
}

\begin{abstract}
Style called Art Nouveau appeared in the last quarter of the XIX century in Austria-Hungary and quickly spread throughout Europe. This style has reached the heyday in Russia in the end of the 1890s-1900s. The object of classic Art Nouveau style characterized by the asymmetrical facades, the almost full abandonment of historical decorative elements, the extensive use of the plant ornaments, and other characteristic feature was considered in this paper on the example of the F.P. Efremov's mansion in Cheboksary, Russia. The project of building reconstruction was also proposed.
\end{abstract}

\section{Introduction}

Considered object was built in 1911 on the project of an unknown architect. The building was erected in the historical center of Cheboksary, on the River Volga embankment [1]. Efremov's mansion - two-store asymmetric building, with the measurements of 27 to 24 meters (Fig. 1-2). Currently, Chuvash State Art Museum department occupies the mansion. A combination of light-green and white plaster, metal, plaster decorative elements are used in the finishing of the facades [2,3].

The composition of the mansion is based on the different-sized volume combination, free arrangement of the facades, particularly two avant-corps with different-shaped curved gables. Complicated-profiled cornice with brackets, supporting the beaked canopy of the roof, passes through the top of the building. The pilasters with the square capitals, decorated with three vertical grooves, garland and round rosette, punctuate the corners of the each volume. The building has four multiscale balconies with wrought iron railings, one on each side. The enclosure of the roof is a combination of the cast-iron grate and stone pedestals with metal lids [4-6].

The main entrance is located in the submerged left corner of the building; the porch is decorated with the canopy, which serves as a basis for the balcony-loggia on the second floor. The fence, which traditionally includes gate and wicket, links to the left side of the building and connects it with the wing.

\footnotetext{
* Corresponding author: coolhabit@yandex.ru
} 


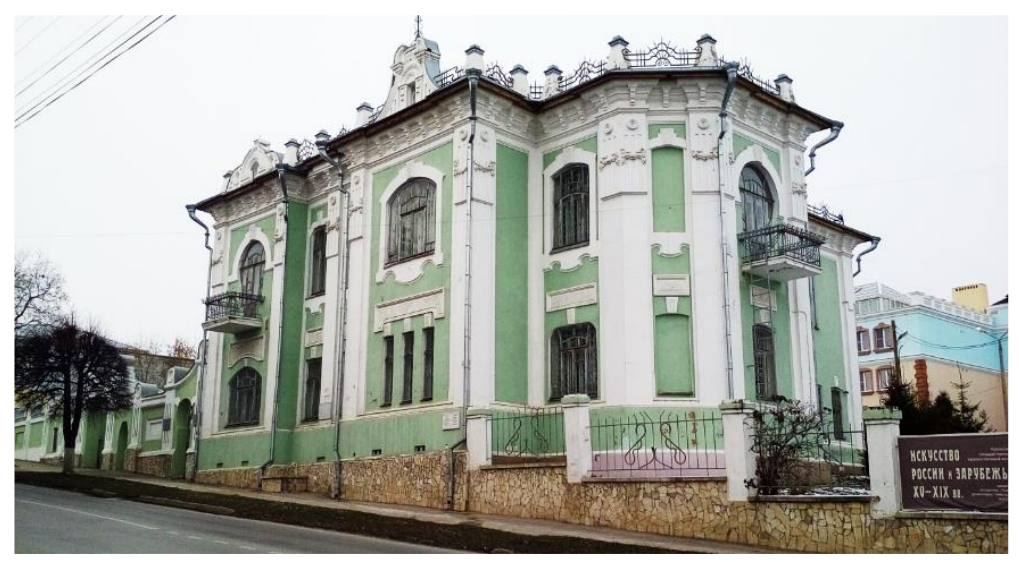

Fig. 1. Southern and eastern facades of the Efremov`s mansion.

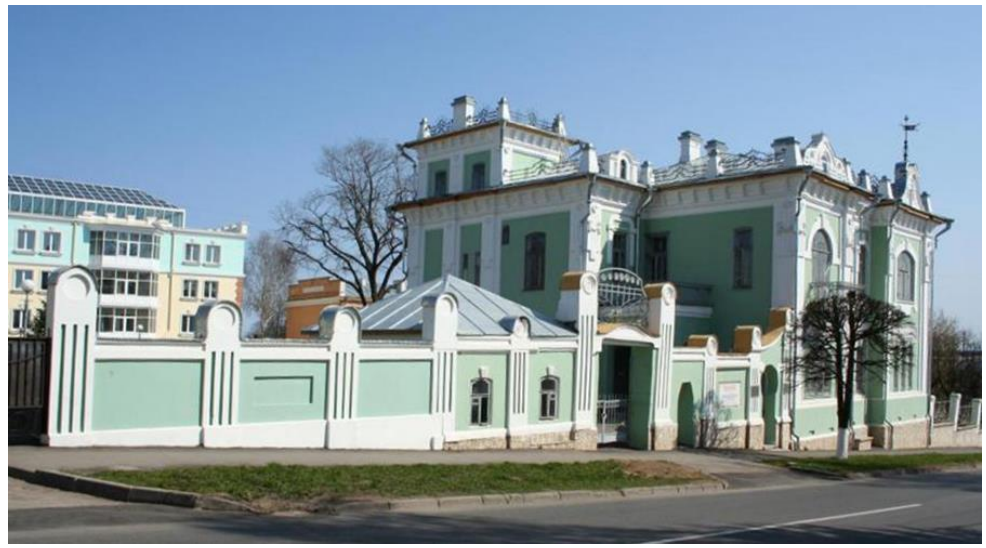

Fig. 2. Western and southern facades of the Efremov`s mansion.

\section{Materials and methods}

\subsection{Stylistic differences of the Efremov's mansion from the classic Art Nouveau mansions}

As was mentioned above, there is a lack of attention was given to the provincial Art Nouveau buildings in the basic research of Russian architecture of the early XX century. Consequently, the question about the differences between provincial buildings and capital buildings, according to the authors, was not enough studied [7].

Authors made a comparison between the Efremov`s mansion and the most famous examples of the Art Nouveau mansion: Ryabushinsky`s mansion in Moscow (1903), Kshesinskaya`s mansion in the Saint-Petersburg (1906). The comparison was made on the formal features. The results are presented in the Table 1. 
Table 1. Comparison results.

\begin{tabular}{|c|c|c|c|}
\hline $\begin{array}{l}\text { Characteristic features } \\
\text { of classic Art Nouveau }\end{array}$ & $\begin{array}{l}\text { Ryabushinsky`s } \\
\text { mansion }\end{array}$ & $\begin{array}{c}\text { Kshesinskaya`s } \\
\text { mansion }\end{array}$ & F.P. Efremov`s mansion \\
\hline $\begin{array}{l}\text { Free construction plan } \\
\text { and volume of the } \\
\text { building }\end{array}$ & Presence & Presence & Presence \\
\hline $\begin{array}{l}\text { Use of decorative } \\
\text { elements, based on the } \\
\text { natural objects }\end{array}$ & $\begin{array}{l}\text { Widely used in } \\
\text { the exterior and } \\
\text { interior }\end{array}$ & $\begin{array}{l}\text { Presented mainly in } \\
\text { the exterior, partly } \\
\text { in the interior }\end{array}$ & $\begin{array}{l}\text { Facades - floral motifs; } \\
\text { interiors - decoration of } \\
\text { the furnaces, fireplaces } \\
\text { and metal ladders }\end{array}$ \\
\hline $\begin{array}{l}\text { Refusal from the } \\
\text { historical decorative } \\
\text { elements }\end{array}$ & Not used & $\begin{array}{l}\text { Facades - not used; } \\
\text { interiors - elements } \\
\text { of neoclassicism } \\
\text { and eclecticism can } \\
\text { be traced }\end{array}$ & $\begin{array}{l}\text { Baroque gable is placed } \\
\text { above on of the avant- } \\
\text { corps; interior - } \\
\text { Baroque motifs are } \\
\text { widely used }\end{array}$ \\
\hline $\begin{array}{l}\text { Use of the characteristic } \\
\text { Art Nouveau finishing } \\
\text { materials }\end{array}$ & $\begin{array}{l}\text { Practically full } \\
\text { diapason of the } \\
\text { classic Art } \\
\text { Nouveau finishing } \\
\text { materials is used } \\
\text { in the interiors } \\
\text { and on the facades }\end{array}$ & $\begin{array}{l}\text { Majolica, glazed } \\
\text { bricks roughly axed } \\
\text { granite are used on } \\
\text { the facades; stained } \\
\text { glass - in the } \\
\text { interiors }\end{array}$ & Not used \\
\hline $\begin{array}{l}\text { Identify of the bearing } \\
\text { structures on the facade }\end{array}$ & Not revealed & $\begin{array}{l}\text { Window lintels of } \\
\text { the l-beams, } \\
\text { console canopies } \\
\text { above the entrance } \\
\text { are revealed }\end{array}$ & Not revealed \\
\hline $\begin{array}{l}\text { Use of the openings, } \\
\text { which are characterized } \\
\text { to the classic Art } \\
\text { Nouveau }\end{array}$ & $\begin{array}{l}\text { Used on the } \\
\text { facades and in the } \\
\text { interiors }\end{array}$ & $\begin{array}{l}\text { Used mainly on the } \\
\text { facades }\end{array}$ & $\begin{array}{l}\text { Used mainly on the } \\
\text { facades }\end{array}$ \\
\hline
\end{tabular}

By analyzing these data, it can be stated, that Efremov's mansion is represented as a work of the qualified architect and based on the primary principals of the Art Nouveau style.

\subsection{Design features - bearing structures}

The brick and wood are used as the basic building materials of the bearing structures. The use of the brick as a wall material is confirmed by the presence of the masonry, which could be peeped through the breakaway plaster. Masonry is in the satisfactory condition. The chips, cracks and peeling finish could be noticed in the lower part of the building. This is associated with the impaired waterproof. Typical sediment cracks on the walls are not observed [8-10].

The only element of a hardwood floors, available for observation, is an additional wooden cornice between the roof and plastered white cornice. Cracks, caused by the leaks or minor strains in the hardwood floor are visible on the ceiling plaster of the second floor. According to the one of the authors, aforementioned cracks on the ceiling plaster could be eliminated in the repairing process or restoration, they no longer occur without the leaks [11]. 


\subsection{Architectural features - exteriors, interiors, finishing materials}

Coloured plaster and plaster decorative elements was mostly used in the exterior. There is no information about original colour of the plaster and painting. The original building had the light shade paint. After twenty years, it was covered with the layer of dirt, or it was repainted in dark colour, according to the photos. In the early 2000s the mansion was painted in burgundy colour in combination with white. The light facing stone faced the gate, fence and lower part of the ground floor. Later, the burgundy colour was replaced by malachite green [12].

Nowadays, the main colour of the building is close to the grey-green combined with white. The status of the finishing is insufficient. The plaster on the outer walls is cracked; the paint is peeled and exfoliated. The yard façade and ground floor are painted with the different colours and shades. The finishing of the ground floor - facing stone - is covered by the cracks and breaks-off [13].

The stucco on the facades is in sufficient condition. Metal parts of the building facades are in the different state of conservation. The galvanized visor of the inner porch is bend. The metal ebbs on the windows are strained. The galvanized pipes are in sufficient condition. The elements of artistic forging almost lost a layer of paint and began to be covered with rust, especially on the balcony railings.

The wooden parts of the façade are in the similar situation: the window frames lost its paint; the wood is split to the fibre $[14,15]$.

\subsection{Heating system - design, elements and technical condition}

Heating system of the considered object is a variant of «air» system, which was developed by engineer N.A. Amosov in the first half of the XIX century. Proposed method is much more economical, that conventional furnace heating and it also performs the ventilation function. The furnace and the outside air intake system were located in the basement. Pipes, which feed the heated air from the furnace, pass from the basement through the first and the second floors and locate in the inner walls between two or three rooms, providing the highest efficiency and minimum heat loss. Hot air passes through the series of hear radiating, like Dutch ovens, to increase the heat $[16,17]$.

Now the mansion is not heated with the Amosov system. It was replaced by the central heating system, by placing the metal radiators in the rooms. Most part of the furnace fittings was preserved to nowadays in perfect condition, so as the ovens.

\section{Results}

A series of works in the F.P. Efremov`s mansion are necessary to be done, such as bearing structures, decoration of facades and interior renovation.

- The reason of the leaks and cracks on the ceiling should be determined: it is a problem only of a leaking galvanized roof or the wooden beams are strained. Taking the latter, the roof needs to be fixed by reinforcing its structure.

- Side leakage on the walls, which was caused by the precipitations from roof, should be eliminated. The reason may be in the gutter, which is rather small and could splash the water on the wall.

- Wall facing of the plinth and bottom of the first floor gets wet and breaks down. The waterproofing of the foundation is needed, which can be performed by digging a trench around the basement. Mastic and ruberoid also should be used, by covering the foundation and bottom parts of the walls.

- Broken part of stucco garland on the façade should be restored. 
- The historical finishing should be restored. Original type and colour can be determined by the removing of the latest layers of the paint and plaster.

- Old peeled painting and rust should be removed from the metal parts of the balconies, fences of the roofs, canopy of the inner porch and metal grills between the window frames. They must be covered with the corrosion inhibitor and applied with the new paint, similar to historic.

- Old layers of the paint from the windows must be removed, the wood should be sanded and covered by the primer and applied with the paint, similar to historic. The same concept should be applied to the doors of the balconies. If any of the wooden elements would not meet the strength requirements, they must be replaced by absolutely identical.

- Old paint and plaster should be removed from the walls and ceilings in the mansion, which require repair, before the application of new one. Some cracks on the ceiling may be disguised without drastic measures.

- It is necessary to restore parquet flooring by removing the old remnants, sanding and covering with a new layer of varnish.

- Small-chipped stoneware tiles should be filled out with the same material with the same colour.

- Joints between the furnaces tiles should be cleaned and renewed. Pattern should be restored on the tiles with damaged coating.

- Modern humidifiers should be set in the museum halls in order to preserve the collection.

- The information about original chandeliers should be found. Similar or in appropriate style of Art Nouveau in 1911 chandeliers should be set.

\section{Summary}

F.P. Efremov`s mansion is a memorable example of an architecture, which is one of the few sites of Art Nouveau style in the Cheboksary. The age of a building is more than a century, so it requires the measure for its preservation. Firstly, bearing structures should be checked to ensure its reliability, and take some measures, if it is necessary. Following, the windows, doors, metal constructions, internal and external decoration should be renovated. Also, when the foundation, drainage system renovation will take place, the hydrological terms of exploitation, hydrological properties of the soil researches must be taken into account to prevent the ecological-economic damage [19-22]. Such a works, taken together with reliable care and monitoring are the necessary for the long-term stable [23-29] condition of the building.

\section{References}

1. P. Greenhalgh, Art Nouveau, 1890-1914 (London: V\&A, 2000).

2. J.-P. Bouillon, Journal de L'Art Nouveau (Paris: Skira, 1985).

3. A. Duncan, Art Nouveau. World of Art (New York: Thames and Hudson, 1994).

4. S. Heller, C. Seymour, Graphic Style from Victorian to Digital (New ed. New York: Harry N. Abrams, Inc., 2001).

5. D.L. Silverman, Art Nouveau in Fin-de-siècle France: Politics, Psychology, and Style (1992).

6. G. Campbell, The Grove Encyclopedia of Decorative Arts (Oxford: Oxford University Press, 2006). 
7. M. Eleb, A. Debarre, L'invention de l'habitation moderne: Paris 1880-1914 (Paris: Editions Hazan, 1995).

8. A. Duncan, L. Majorelle, Master of Art Nouveau Design (New York: Abrams, 1991).

9. W.C. Brumfield, The Origins of Modernism in Russian Architecture (Berkley: University of California Press, 1991).

10. I. Andreescu, A. Keller, M. Mosoarca, Procedia Engineering, 161, 1204-1210 (2016).

11. K. Pudelska, A. Miroslaw, Acta Agrobotanica, 68, 99-108 (2015).

12. L.S. Kosheleva, Russian Studies in Philosophy, 53, 72-86 (2015).

13. A.M. Lluch, F. Vegas Lopez-Manzanares, C. Mileto, M. Diodato, Advanced Materials Research, 778, 620-627 (2013).

14. M. Boutoulle, Connaissance des Arts, 716, 60-64 (2013).

15. G. Kruppa, Transsylvania Nostra, 1, 17-24 (2013).

16. F. Sandrolini, E. Franzoni, R. Nakonieczny, Informes de la Construcción, 63, 5-11 (2011).

17. J. Friedrichs. European approaches to international relations theory: A house with many mansions (Routledge Taylor \& Francis Group, 2004). 